\title{
$\gamma$-Catenin is regulated by the APC tumor suppressor and its oncogenic activity is distinct from that of $\beta$-catenin
}

\author{
Frank T. Kolligs, ${ }^{1}$ Barbara Kolligs, ${ }^{1}$ Karen M. Hajra, ${ }^{1,4}$ Gang Hu, ${ }^{1,5}$ Masachika Tani, ${ }^{1}$ \\ Kathleen R. Cho, ${ }^{1,3}$ and Eric R. Fearon ${ }^{1-4,6}$ \\ Division of Medical Genetics and the Cancer Center, Departments of ${ }^{1}$ Internal Medicine, ${ }^{2}$ Human Genetics, and ${ }^{3}$ Pathology \\ and the ${ }^{4}$ Program in Cellular and Molecular Biology, University of Michigan School of Medicine, Ann Arbor, Michigan \\ 48109 USA
}

\begin{abstract}
$\boldsymbol{\beta}$-Catenin and $\boldsymbol{\gamma}$-catenin (plakoglobin), vertebrate homologs of Drosophila armadillo, function in cell adhesion and the Wnt signaling pathway. In colon and other cancers, mutations in the APC tumor suppressor protein or $\beta$-catenin's amino terminus stabilize $\beta$-catenin, enhancing its ability to activate transcription of Tcf/Lef target genes. Though $\beta$ - and $\gamma$-catenin have analogous structures and functions and like binding to APC, evidence that $\gamma$-catenin has an important role in cancer has been lacking. We report here that APC regulates both $\beta$ - and $\gamma$-catenin and $\gamma$-catenin functions as an oncogene. In contrast to $\beta$-catenin, for which only amino-terminal mutated forms transform RK3E epithelial cells, wild-type and several amino-terminal mutated forms of $\gamma$-catenin had similar transforming activity. $\gamma$-Catenin's transforming activity, like $\beta$-catenin's, was dependent on Tcf/Lef function. However, in contrast to $\beta$-catenin, $\gamma$-catenin strongly activated c-Myc expression and c-Myc function was crucial for $\gamma$-catenin transformation. Our findings suggest APC mutations alter regulation of both $\beta$ - and $\gamma$-catenin, perhaps explaining why the frequency of $A P C$ mutations in colon cancer far exceeds that of $\beta$-catenin mutations. Elevated c-Myc expression in cancers with APC defects may be due to altered regulation of both $\beta$ - and $\gamma$-catenin. Furthermore, the data imply $\beta$ - and $\gamma$-catenin may have distinct roles in Wnt signaling and cancer via differential effects on downstream target genes.
\end{abstract}

[Key Words: $\gamma$-catenin; plakoglobin; $\beta$-catenin; cancer; Tcf/Lef; c-Myc; Wnt signaling]

Received January 12, 2000; revised version accepted April 6, 2000.

$\beta$-Catenin and $\gamma$-catenin (also known as plakoglobin) are vertebrate homologs of Drosophila armadillo, a protein initially identified because of its role in cell fate determination and segment polarity (Peifer and Wieschaus 1990; Peifer et al. 1991). Like armadillo, $\beta$ - and $\gamma$-catenin function in cell adhesion and the wingless/Wnt signaling pathway (Cadigan and Nusse 1997; Barth et al. 1997; Willert and Nusse 1998; Behrens 1999|. Whereas both $\beta$ and $\gamma$-catenin are present in adherens junctions, where they link E-cadherin via $\alpha$-catenin to the actin cytoskeleton, $\gamma$-catenin is also present in desmosomes, where it interacts with desmoglein and desmocollin (Ben-Ze'ev and Geiger 1998). The highly conserved central regions of $\beta$ - and $\gamma$-catenin consist of 12 armadillo repeats, and these repeats facilitate binding to various proteins, including E-cadherin, $\alpha$-catenin, the adenomatous polyposis coli (APC) tumor suppressor, T-cell factor/lymphoid enhancer factor (Tcf/Lef) transcription factors, and axin/

\footnotetext{
${ }^{5}$ Present address: Parke-Davis Research Division of Warner-Lambert, Ann Arbor, Michigan 48105 USA.

${ }^{6}$ Corresponding author.

E-MAIL fearon@umich.edu; FAX (734) 647-7979.
}

conductin proteins (Ben-Ze'ev and Geiger 1998; Willert and Nusse 1998; Behrens 1999). The amino-terminal domains of $\beta$ - and $\gamma$-catenin share modest similarity, including presumptive regulatory sequences that are phosphorylated by glycogen synthase kinase $3 \beta$ (GSK3 $\beta$ ) (Moon and Miller 1997; Ben-Ze'ev and Geiger 1998; Willert and Nusse 1998; Bienz 1999). Though the carboxyterminal sequences of $\beta$ - and $\gamma$-catenin are not closely related, both carboxy-terminal domains appear to function in transcriptional activation (Simcha et al. 1998). $\beta$-Catenin's amino-terminal domain may also function in transcriptional activation (Hsu et al. 1998; Simcha et al. 1998; Kolligs et al. 1999), but no such function has yet been ascribed to the corresponding region of $\gamma$-catenin.

Regulation of the free (nonmembrane bound) pools of $\beta$-catenin by the Wnt pathway has been extensively studied (for review, see Ben-Ze'ev and Geiger 1998; Willert and Nusse 1998; Bienz 1999; Peifer and Polakis 2000; Salic et al. 2000). In brief, Wnts are secreted proteins that activate transmembrane Frizzled receptors, ultimately leading to inhibition of GSK3 $\beta$ activity. GSK3 $\beta$, when active and complexed with APC and axin/conductin proteins, phosphorylates specific serine and/or threonine residues near the $\beta$-catenin amino terminus. The phos- 
phorylated forms of $\beta$-catenin bind to the F-box protein $\beta$-TrCP (Hart et al. 1999; Kitagawa et al. 1999; Winston et al. 1999|, a subunit of the SCF-type E3 ubiquitin ligase complex (Maniatis 1999), and this complex facilitates ubiquitination and subsequent proteasome degradation of $\beta$-catenin. Though $\gamma$-catenin regulation has been less extensively studied than that of $\beta$-catenin, $\gamma$-catenin can bind to APC (Hulsken et al. 1994; Shibata et al. 1994; Rubinfeld et al. 1995), and axin and GSK3 $\beta$ modulate $\gamma$-catenin levels in certain settings (Kodama et al. 1999). Thus, $\gamma$-catenin may be regulated much like $\beta$-catenin. Following Wnt pathway activation, both $\beta$ - and $\gamma$-catenin accumulate in the cytoplasm and nucleus, where they bind to members of the Tcf/Lef transcription factor family (Ben-Ze'ev and Geiger 1998; Willert and Nusse 1998). In the nucleus, Tcf/Lef factors mediate sequence-specific DNA binding, and $\beta$ - and $\gamma$-catenin serve as transcriptional activators. Presumptive $\beta$-cateninTcf/Lef-regulated genes include c-MYC (He et al. 1998), cyclin D1 (Shtutman et al. 1999; Tetsu and McCormick 1999), matrilysin/MMP-7 (Crawford et al. 1999), Tcf-1 (Roose et al. 1999), and PPARס (He et al. 1999).

Defects in the Wnt pathway play an important role in cancer. In human tumors, the most frequent defects in this pathway lead to inactivation of APC or activation of $\beta$-catenin (Behrens 1999; Polakis 1999). In $70 \%-80 \%$ of all colorectal cancers, $A P C$ mutations result in either no protein production or the synthesis of a truncated APC protein that can no longer efficiently facilitate $\beta$-catenin's phosphorylation by the GSK3 $\beta$ /axin complex (Kinzler and Vogelstein 1996; Bienz 1999; Peifer and Polakis 2000). In a fraction of colorectal cancers lacking $A P C$ mutations as well as cancers of other types, mutations of presumptive GSK3 $\beta$ phosphorylation sites near the amino terminus of $\beta$-catenin result in its stabilization and ability to enhance Tcf/Lef target gene transcription (Polakis 1999). Intriguingly, despite the similar structures and functions of $\beta$ - and $\gamma$-catenin, including their binding to APC, no $\gamma$-catenin mutations have been reported in human cancer, with the exception of an aminoterminal missense substitution in one gastric cancer cell line (Caca et al. 1999). In fact, wild-type $\gamma$-catenin was reported to exert tumor suppressive effects upon its overexpression in some cancer cells (Simcha et al. 1996).

Because of the absence of definitive data on the role of $\gamma$-catenin in colon and other cancers, we examined its regulation and oncogenic potential. Our results indicate APC regulates $\gamma$-catenin akin to $\beta$-catenin in colon cancer cells, and wild-type $\gamma$-catenin can function as an oncogene when its expression is deregulated. The oncogenic activity of wild-type $\gamma$-catenin distingushes it from $\beta$-catenin, which requires amino-terminal mutations for oncogenic activation (Kolligs et al. 1999). Furthermore, in contrast to results for $\beta$-catenin (Kolligs et al. 1999), multiple lines of evidence indicate c-Myc is a critical factor in $\gamma$-catenin transformation. Our findings offer new insights into the contribution of APC defects in cancer development and highlight potentially critical differences between the functions of $\beta$ - and $\gamma$-catenin in Wnt signaling and regulation of Tcf/Lef target genes.

\section{Results}

APC regulates $\beta$ - and $\gamma$-catenin in colon cancer

As reviewed above, the APC tumor suppressor protein has been shown to bind both $\beta$ - and $\gamma$-catenin. The ability of APC to regulate $\beta$-catenin in the cytosol and nucleus has been demonstrated (Munemitsu et al. 1995; Inomata et al. 1996; Hayashi et al. 1997; Kawahara et al. 2000), as have APC's effects on $\beta$-catenin's ability to activate Tcf/Lef transcription (Korinek et al. 1997). These effects have been shown largely via approaches where a wild-type version of the $A P C$ gene has been transiently overexpressed in colon cancer cells with defective $A P C$ alleles. We sought to determine if restoration of APC function in colon cancer cells had similar effects on $\gamma$-catenin, and we were interested in a system where APC expression could be rapidly induced to essentially physiological levels. Prior work by Morin et al. (1995) yielded a system well suited for our studies. The HT29 colon cancer line has truncating mutations in both APC alleles. Morin et al. (1995) generated an HT29 line (HT29-APC) in which, following zinc exposure, expression of an exogenous wild-type APC protein is rapidly induced to roughly the same level as that of the endogenous truncated APC proteins. Using HT29-APC cells and a matched control line (i.e., HT29-Gal; Morin et al. $1995)$, we characterized $\beta$ - and $\gamma$-catenin expression by immunofluorescence at baseline and following zinc exposure. Prior to induction of wild-type APC, $\gamma$ - and $\beta$-catenin were located at cell-cell borders as well as diffusely throughout the cytoplasm and nucleus (Fig. 1a,c, respectively). However, by $6 \mathrm{hr}$ after exposure of the cells to zinc, $>60 \%$ of the cells displayed considerably reduced levels of $\gamma$ - and $\beta$-catenin in the cytoplasm and nucleus (Fig. 1b,d, respectively). No changes in $\gamma$ - or $\beta$-catenin staining were seen in the control HT29-Gal cells following zinc treatment (data not shown). To obtain further evidence that alterations in $\gamma$-catenin levels and localization often parallel those of $\beta$-catenin in colorectal cancer, we carried out immunohistochemical studies of $\beta$ - and $\gamma$-catenin in 12 primary colorectal carcinoma specimens. Whereas $\beta$ - and $\gamma$-catenin showed predominantly a membrane localization in normal colonic mucosa cells (Fig. 1e,g,i,i), in 8 of the 12 carcinomas, we observed increased staining of both $\beta$ - and $\gamma$-catenin in the cytoplasm (Fig. 1f,h-i). In a subset of the carcinomas, focal nuclear staining for $\beta$-catenin was observed (Fig. $1 i)$, though nuclear staining for $\gamma$-catenin was not seen. Taken together, the data from the immunofluorescence and immunohistochemical studies suggest APC regulates both $\beta$ - and $\gamma$-catenin in colon cancer cells.

\section{$\gamma$-Catenin expression and Tcf/Lef transcription activation}

Our previous work established that $\beta$-catenin proteins with mutations in presumptive amino-terminal phosphorylation sites promoted neoplastic transformation of RK3E, an adenovirus E1A-transformed rat kidney epithe- 

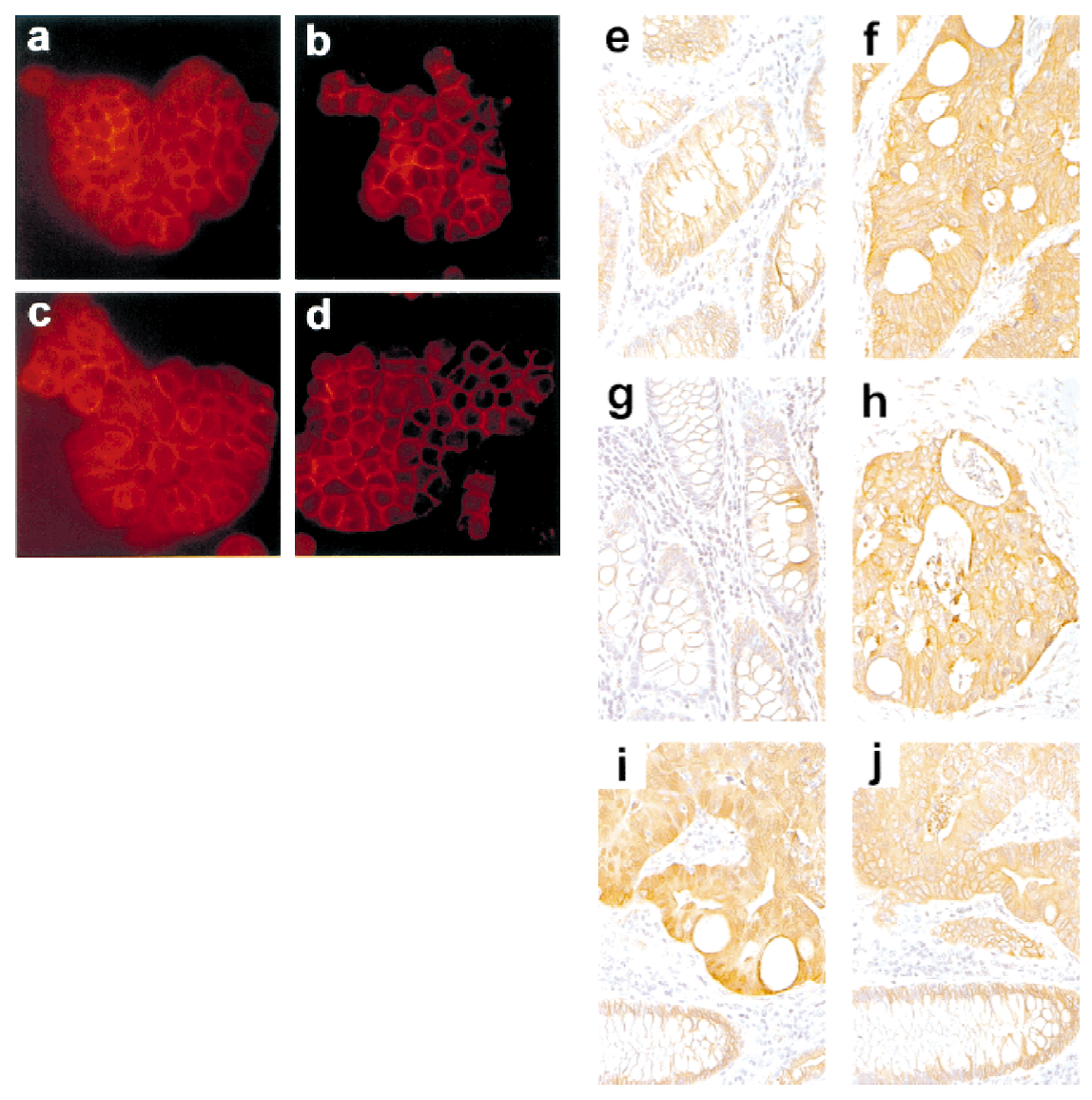

shown in $g, h$ and $j$. Whereas $\beta$ - and $\gamma$-catenin were predominantly localized to the ment increased cytoplasmic staining for $\beta$ - and $\gamma$-catenin was seen in carcinoma cells. Nuclear staining for $\beta$-catenin is seen in $i$, but no nuclear staining for $\gamma$-catenin is seen. The slides were photographed at $400 \times$.

lial line, whereas wild-type $\beta$-catenin failed to function as an oncogene in RK3E (Kolligs et al. 1999). The finding that APC regulated $\gamma$-catenin motivated us to pursue studies of $\gamma$-catenin's transforming activity in RK3E. We first generated expression constructs encoding wild-type $\gamma$-catenin and deletion mutants (Fig. 2A). The rationale for creating the $\Delta \mathrm{N} 38 \gamma, \Delta \mathrm{N} 122 \gamma, \Delta \mathrm{Arm} \gamma$, and $\Delta \mathrm{C} 687 \gamma$ deletion mutants was based on the conserved structures of $\gamma$ - and $\beta$-catenin and prior data on the oncogenic activity of various $\beta$-catenin deletion mutants (Kolligs et al. 1999). In addition, because the only $\gamma$-catenin mutation reported in cancer was a missense mutation of a potential phosphorylation site at the amino terminus (codon 28, serine-to-leucine mutation) (Caca et al. 1999), we also prepared an expression construct encoding the S28L mutant.

The expression of wild-type and mutated forms of $\gamma$-catenin was compared with that of wild type $\beta$-catenin and a mutated form carrying a cancer-derived missense substitution (S33Y) in $\beta$-catenin's presumptive GSK3 $\beta$ phosphorylation sequences, using Western blotting to detect the carboxy-terminal Flag epitope tag present on each $\gamma$ - and $\beta$-catenin protein. Whereas a single missense mutation or in-frame deletions of the presumptive amino-terminal phosphorylation sites consistently sta- bilized the $\beta$-catenin protein (Fig. 2B; Kolligs et al. 1999), the S28L mutation did not increase $\gamma$-catenin expression over the levels of the wild-type protein (Fig. 2B). However, larger in-frame deletions of the amino terminus led to increased $\gamma$-catenin expression (Fig. 2B, $\Delta$ N38 and $\Delta$ N122 mutants), implicating $\gamma$-catenin's amino terminus in the regulation of its degradation. Deletion of armadillo repeats 3-8 also led to increased $\gamma$-catenin expression (Fig. 2B, $\Delta$ Arm), consistent with the notion that the APC and conductin/axin proteins bind sequence in this region of $\gamma$-catenin and regulate its degradation.

The ability of the various $\gamma$-catenin proteins to activate Tcf/Lef transcription was then assessed, using a model reporter gene construct containing three Tcf-binding sites upstream of a minimal c-Fos-derived promoter element and luciferase coding sequences (i.e., TOPFLASH). As in prior studies (Kolligs et al. 1999), the S33Y mutated form of $\beta$-catenin had about $8-10 \times$ the activity of wild-type $\beta$-catenin (Fig. $2 \mathrm{C}$ ). In contrast, only roughly $30 \%-50 \%$ increases in Tcf/Lef activation were seen for the $\Delta \mathrm{N} 38$ and S28L mutated forms of $\gamma$-catenin, respectively, when compared with wild-type $\gamma$-catenin (Fig. 2C). These three $\gamma$-catenin proteins all had less activity than wild-type $\beta$-catenin in the assay, though the activ- 
Kolligs et al.

A
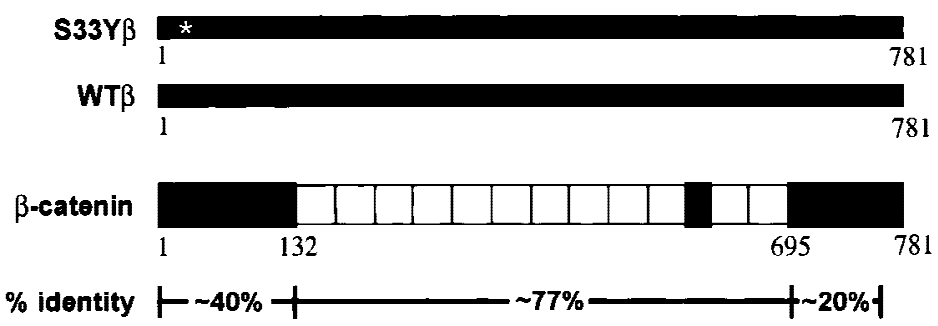

$\gamma$-catenin
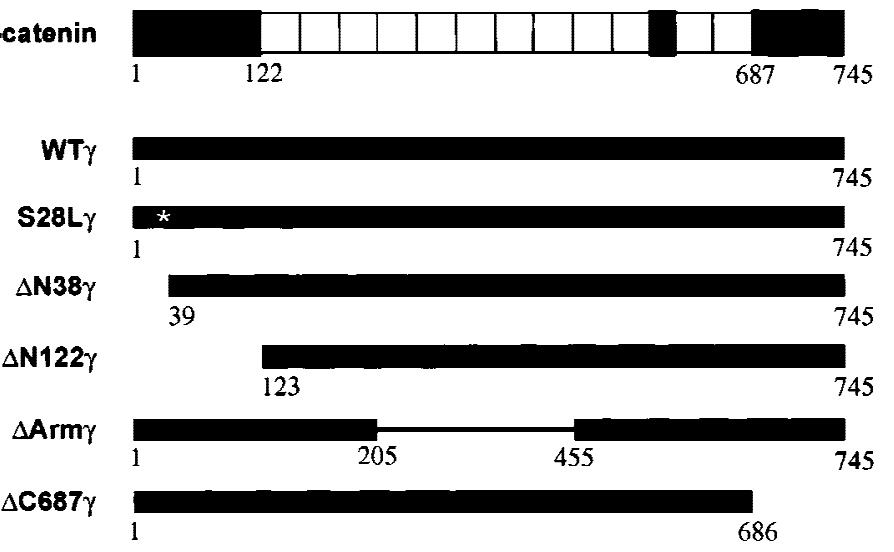

B
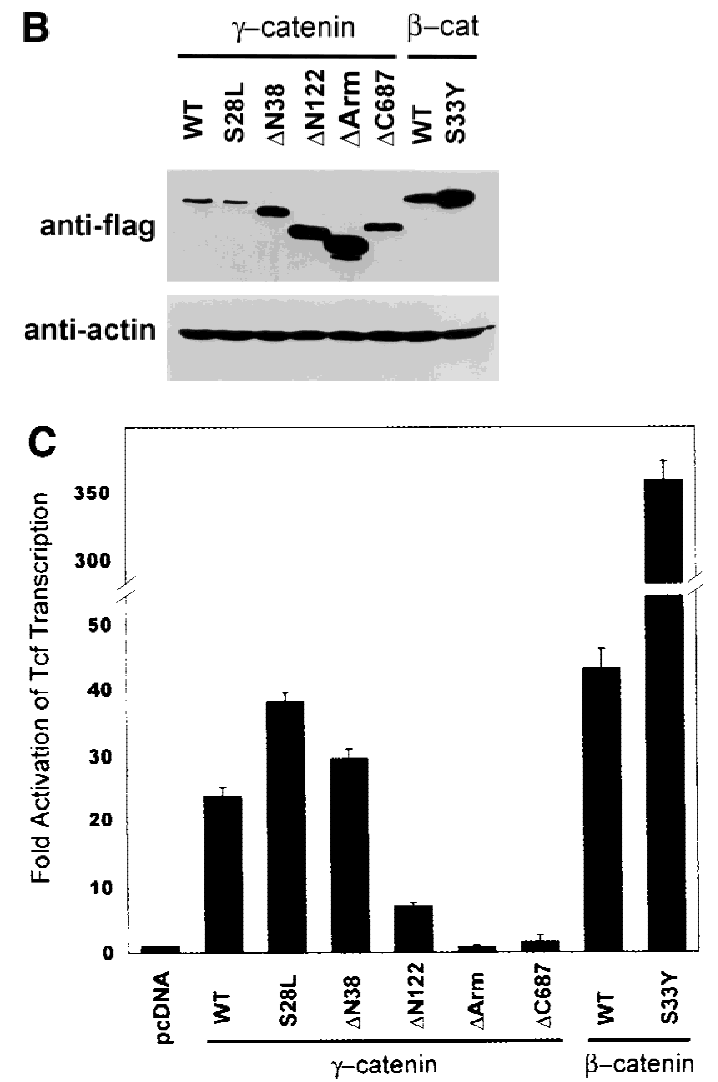

Figure 2. Expression of wild-type and mutated $\gamma$ - and $\beta$-catenin proteins and their effects on Tcf transcription in 293 cells. $(A)$ Schematic illustration of the structure of 745 -amino-acid $\gamma$-catenin and 781 -amino-acid $\beta$-catenin proteins; the percentage identity of sequences in different regions of the proteins; and the $\gamma$ - and $\beta$-catenin proteins encoded by the expression constructs used in this work. The 12 armadillo repeats in the highly conserved central regions of $\gamma$ - and $\beta$-catenin are indicated by open boxes. In addition to wild-type $\gamma$ - and $\beta$-catenin, several mutant proteins were expressed. Asterisks $\left(^{\star}\right)$ indicate the position of point mutations (i.e., S33Y $\beta$ and S28L $\gamma$ ), and the thin line indicates the region of $\gamma$-catenin affected by an in-frame deletion in the $\Delta$ Arm $\gamma$ construct. All $\gamma$ - and $\beta$-catenin proteins were modified to contain carboxy-terminal Flag epitope tags. $(B)$ Expression of wild-type and mutated $\gamma$ - and $\beta$-catenin proteins. ECL-Western blot analysis with an anti-Flag antibody was carried out on whole-cell lysates prepared $48 \mathrm{hr}$ after transfection of 293 cells with pcDNA3 constructs encoding the $\gamma$ - and $\beta$-catenin proteins. To confirm equal loading and transfer of proteins, blots were stripped and ECL-Western blotting with an anti-actin antibody was performed. (C) Activation of Tcf transcription by wild-type and mutated forms of $\gamma$ - and $\beta$-catenin in 293 cells following transfection of pcDNA3 constructs. The ratios of luciferase activities from the wild-type Tcf reporter (pTOPFLASH) and a mutant Tcf reporter gene construct (pFOPFLASH) were determined 48 hr after transfection. Luciferase activities were normalized for transfection efficiency by cotransfection with a $\beta$-galactosidase-expressing vector. Tcf activation relative to that obtained with empty pcDNA3 vector is shown. The mean values and standard deviations from three experiments are shown.

ity of the S28L mutant approached that of wild-type $\beta$-catenin. Larger deletions of the amino terminus of $\gamma$-catenin (e.g., $\Delta \mathrm{N} 122$ ) as well as deletions of armadillo repeats 3-8 or the carboxyl terminus substantially inhibited or completely abrogated $\gamma$-catenin's ability to activate Tcf/Lef transcription (Fig. 2C). Taken together, the data suggest that, as previously observed for $\beta$-catenin (Hsu et al. 1998; Kolligs et al. 1999), the abilities of $\gamma$-catenin to bind Tcf/Lef factors via sequences in armadillo repeats 3-8 and to activate transcription through carboxy-terminal and perhaps amino-terminal sequences are all crticial for $\gamma$-catenin's function in stimulating Tcf/Lef transcription.

\section{$\gamma$-Catenin promotes neoplastic transformation}

We next assessed the oncogenic activity of wild-type and mutated forms of $\gamma$-catenin in focus formation assays with the RK3E cell line. Consistent with prior results (Kolligs et al. 1999), wild-type $\beta$-catenin failed to induce transformation, whereas the S33Y mutated form of $\beta$-catenin produced dense foci of morphologically transformed cells in three weeks (Fig. 3A). In contrast to results with $\beta$-catenin, wild-type $\gamma$-catenin had essentially the same transforming activity as two amino-terminal mutated forms of $\gamma$-catenin (S28L $\gamma$ and $\Delta \mathrm{N} 38 \gamma$ ). The ability of $\gamma$-catenin proteins to induce RK3E transformation was correlated with their ability to activate Tcf/Lef transcription, as $\gamma$-catenin mutants defective in Tcf/Lef transcriptional activation, such as $\Delta \mathrm{N} 122 \gamma, \Delta \mathrm{Arm} \gamma$, and $\Delta$ C687 $\gamma$, failed to induce foci (Figs. 2C and 3A). $\gamma$-Catenin was about one-third to one-half as potent as the S33Y mutated form of $\beta$-catenin in the focus forma- 
A

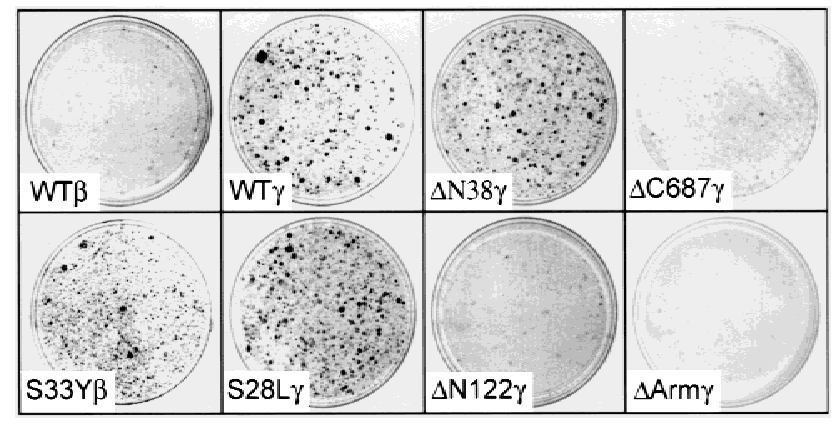

B

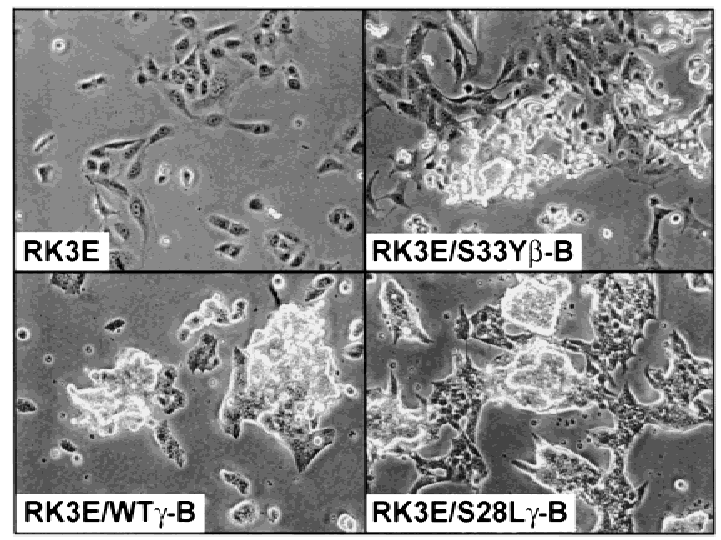

Figure 3. Neoplastic transformation of RK3E cells by $\gamma$-catenin. (A) Focus formation assay in RK3E. RK3E cells were infected with retroviruses encoding wild-type or mutated forms of $\gamma$ - and $\beta$-catenin. Indicated in each panel is the protein encoded by the retrovirus used for infection of the cells. Four weeks after infection, the plates were stained and foci photographed. Representative plates from four or more independent experiments performed on each $\gamma$ - and $\beta$-catenin construct are shown. (B) Morphology of parental RK3E cells, one $\beta$-catenin, and two $\gamma$-catenin transformed cell lines. Magnification for all panels, $200 \times$.

tion assay, though other transforming variants of $\beta$-catenin (e.g., in-frame amino-terminal deletions) have been previously found to possess similarly reduced focus forming activity compared with the S33Y mutant (Kolligs et al. 1999). The $\gamma$-catenin foci were generally larger in size than the S33Y $\beta$-induced foci at equivalent time points (Fig. 3A). Cell lines established from $\gamma$-catenin foci had a distinct morphological appearance when compared with parental RK3E cells or $\beta$-catenin-transformed RK3E lines (Fig. 3B; data not shown), with the $\gamma$-catenintransformed cells generally smaller, more spindleshaped, and growing in tight clusters.

A total of 18 clonal cell lines were established from independent $\gamma$-catenin-induced foci, with 6 lines each from RK3E cells transformed by the wild-type, S28L, or $\Delta \mathrm{N} 38 \gamma$-catenin proteins. All $\gamma$-catenin-transformed lines displayed neoplastic growth properties, including the ability to grow in reduced serum media (Fig. 4A; data not shown) and to form colonies in soft agar (Fig. 4B; data not shown). Four $\gamma$-catenin transformed lines along with a $\beta$-catenin-transformed RK3E line were tested for tumorigenicity in nude mice. Each line formed $>1.5 \mathrm{~cm}$ tumors at 10 of 10 injected sites within 3 weeks (data not shown). All $\gamma$-catenin-transformed lines expressed the transduced wild-type or mutant $\gamma$-catenin protein (Fig. 4C). No consistent increases in the cytosolic or nuclear levels of $\beta$-catenin were seen in the $\gamma$-catenin-transformed RK3E lines (Fig. 4C; data not shown). Hence, $\gamma$-catenin does not appear to transform RK3E merely by increasing $\beta$-catenin levels, a point also well supported by our data showing that $\gamma$-catenin mutants that fail to bind to Tcf and activate transcription do not promote neoplastic transformation (e.g., $\Delta \mathrm{N} 122, \Delta$ Arm, and $\Delta$ C687; Figs. 2C and 3A).

\section{Tcf/Lef deregulation is required for $\gamma$-catenin transformation}

Tcf/Lef transcription activity was measured in all $\gamma$-catenin-transformed lines. Though there was variation in the fold activation of Tcf/Lef transcription in the $\gamma$-catenin-transformed cell lines, all lines displayed elevated transcriptional activity (Fig. 4D). Our prior studies not only demonstrated that Tcf/Lef transcription was constitutively activated in $\beta$-catenin-transformed RK3E lines, but also that transformation by $\beta$-catenin was strongly inhibited in an RK3E cell line expressing a dominant negative Tcf-4 mutant protein (RK3E/Tcf$4 \Delta$ N31; Kolligs et al. 1999). This inhibition of $\beta$-catenin transformation was confirmed, and we also found that $\gamma$-catenin transforming activity was essentially completely inhibited in the RK3E/Tcf- $4 \Delta$ N31 cell line (Fig. $5)$. Therefore, Tcf/Lef factors play a critical role in both $\beta$ - and $\gamma$-catenin transformation.

\section{c-Myc activation is required for $\gamma$-catenin transformation}

Prior work by He et al. (1998) demonstrated that restoration of APC expression in the HT29 colon cancer line strongly repressed expression of c-MYC, a gene well established to function as an oncogene in human cancer when its expression is activated by chromosomal translocation or gene amplification. He et al. (1998) proposed APC inhibited c-MYC via effects on $\beta$-catenin's ability to activate transcription through Tcf-binding elements in the proximal c-MYC promoter. There were, however, some inconsistencies with the data presented in support of the proposed mechanism for APC's effects on c-MYC. Specifically, although APC strongly repressed endogenous c-MYC expression, $\beta$-catenin had only a modest ability to activate expression via the Tcf sites in the cMYC proximal promoter (He et al. 1998). Moreover, in our prior studies, we found c-Myc expression was not consistently activated in $\beta$-catenin transformed RK3E lines and $\beta$-catenin transformation was not inhibited by expression of a dominant negative c-Myc mutant protein (Kolligs et al. 1999). Nevertheless, the hypothesis of $\mathrm{He}$ et al. (1998) regarding the link between APC and c-MYC 
Kolligs et al.

A

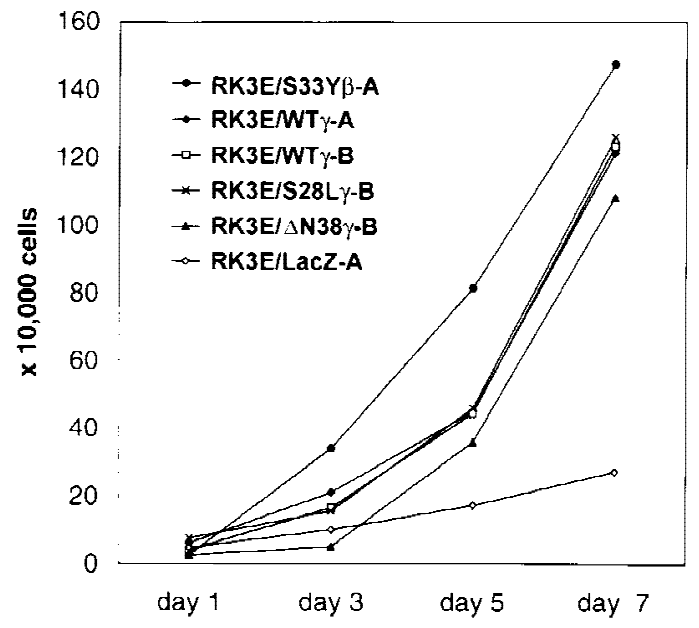

C
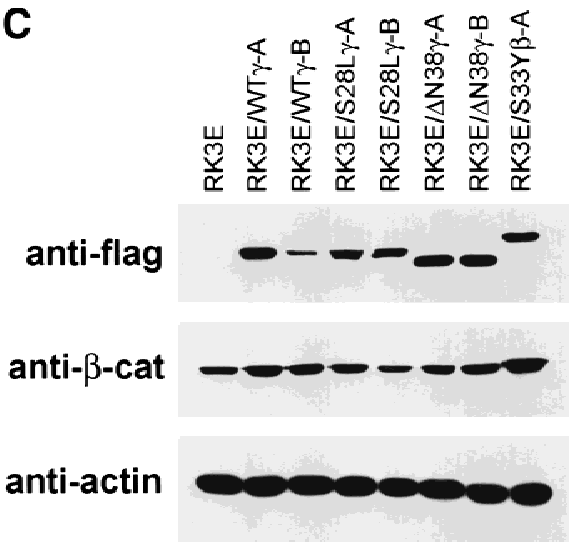

B

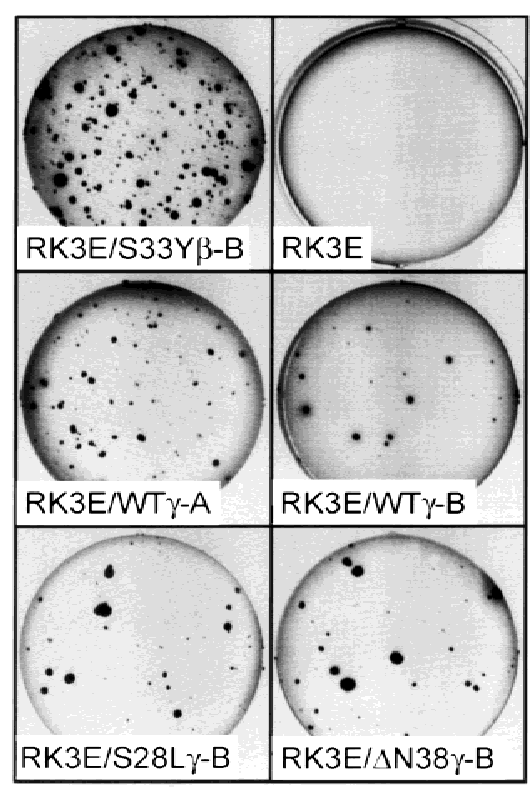

D

Fold Activation of Tcf Transcription (log)

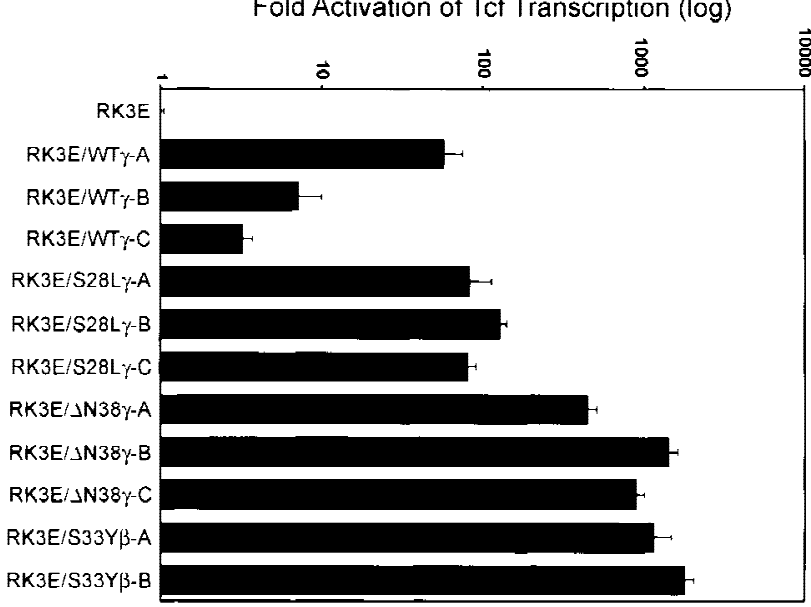

Figure 4. Analysis of $\gamma$-catenin transformed RK3E lines. (A) Growth of $\gamma$-catenin-transformed RK3E lines in medium with $0.5 \%$ FBS. Cells $\left(2 \times 10^{4}\right)$ were initially seeded in $35-\mathrm{mm}$ dishes in the presence of medium containing $10 \%$ FBS, then changed to medium with $0.5 \%$ FBS $24 \mathrm{hr}$ later. Cells were trypsinized and counted at the indicated time points after the switch to $0.5 \%$ FBS. One set of assays representative of three independent experiments is shown. (B) $\gamma$-Catenin-transformed RK3E lines exhibit anchorage independent growth. Colony formation in soft agar was assessed for all transformed lines by plating $1 \times 10^{4}$ cells of each line in $0.3 \%$ agar medium over $0.6 \%$ agar medium underlayers. After 3 weeks, the dishes were stained with methylene blue and photographed. Shown are representative assays for parental RK3E, one $\beta$-catenin transformed line (RK3E/S33Y $\beta$-B), and four independent $\gamma$-catenin lines $(\mathrm{RK} 3 \mathrm{E} / \mathrm{WT} \gamma-\mathrm{A}, \mathrm{RK} 3 \mathrm{E} / \mathrm{WT} \gamma-\mathrm{B}, \mathrm{RK} 3 \mathrm{E} / \mathrm{S} 28 \mathrm{~L} \gamma-\mathrm{B}$, and RK3E/ $\mathrm{NN} 38 \gamma-\mathrm{B})$. (C) Expression of exogenous Flag epitope-tagged $\gamma$ - and $\beta$-catenin proteins and endogenous $\beta$-catenin in transformed RK3E lines. Cytosolic lysates were separated by SDS-PAGE and analyzed by ECL-Western blotting. Expression of the transduced Flag epitope-tagged $\gamma$ - and $\beta$-catein proteins was assessed with an anti-Flag antibody. $\beta$-Catenin levels were determined with an anti- $\beta$-catenin antibody. Equal loading of the lanes was confirmed by stripping the blots and reprobing with an anti-actin antibody. $(D)$ Tcf/Lef transcription is markedly elevated in $\gamma$-catenin-transformed lines compared with parental RK3E cells. The ratio of luciferase activities from a Tcf-responsive reporter (pTOPFLASH) and a control luciferase reporter construct (pFOPFLASH) was determined $24 \mathrm{hr}$ after transfection of the indicated $\gamma$ - and $\beta$-catenin-transformed RK3E lines. Transfection efficiency was assessed with a $\beta$-galactosidase expression vector. Mean values and standard deviations from three independent experiments are shown in logarithmic scale because of the wide range of Tcf activities observed in the lines.

in cancer remained an attractive one to us, because cMYC expression appears to be frequently elevated in colon cancer, despite the absence of genetic alterations at the c-MYC locus (Erisman et al. 1988; Melhem et al. 1992). Hence, we sought to determine whether there might be a relationship between $\gamma$-catenin and c-Myc in 


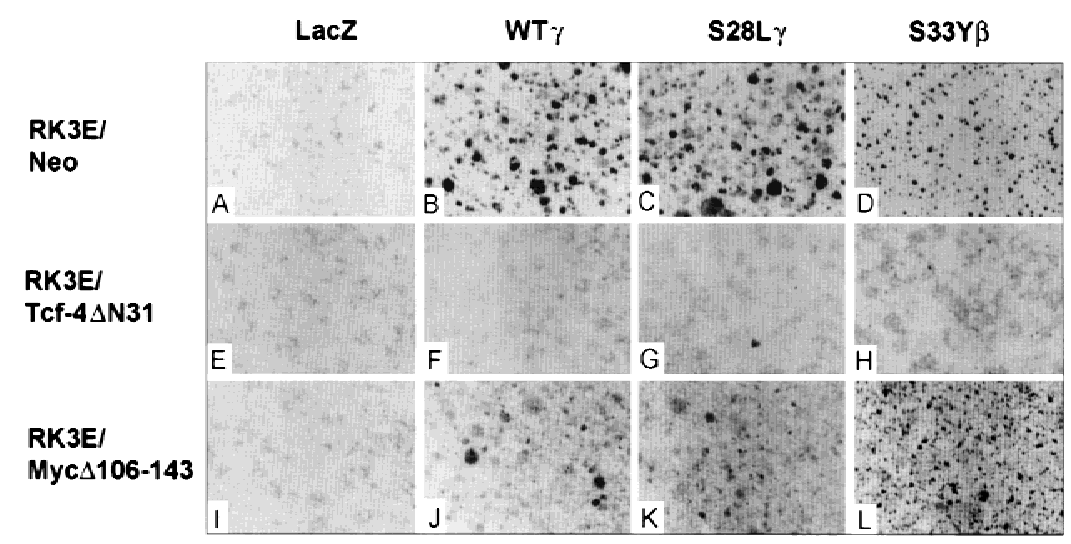

Figure 5. Tcf/Lef factors and c-Myc are required for $\gamma$-catenin transformation. Focus formation assays were carried out in parallel following infection of the RK3E/Neo, RK3E/Tcf$4 \Delta \mathrm{N} 31$, and RK3E/Myc $\Delta 106-143$ cell lines with retroviruses encoding a control LacZ protein, wild-type $\gamma$-catenin, S28L- $\gamma$-catenin, or S33Y- $\beta$ catenin. Four weeks after infection, the plates were stained and photographed. Representative portions of plates from three independent experiments are shown. neoplastic transformation. As shown previously (Kolligs et al. 1999), in focus formation assays with an RK3E cell line expressing a dominant negative c-Myc mutant protein (RK3E/Myc $\Delta 106-143)$, the S33Y $\beta$-catenin mutant protein yielded essentially the same number of foci as in a control cell line (RK3E/Neo) (Fig. 5D,L). In contrast, $\gamma$-catenin's focus-forming activity was strongly inhibited in the RK3E/Myc $\Delta 106-143$ line compared with the RK3E/Neo line (Fig. 5B,C,J,K).

Our findings on the crucial role of c-Myc in $\gamma$-catenin, but not $\beta$-catenin, transformation suggested $\gamma$ - and $\beta$-catenin might differ in their ability to activate $c-M y c$ expression. To address this possibility, we pursued Northern blot studies of c-Myc expression in $\gamma$-catenintransformed RK3E lines. c-Myc expression was greatly increased in all $\gamma$-catenin-transformed lines compared with other RK3E lines, including parental RK3E cells, two $\beta$-catenin-transformed RK3E lines with modestly elevated c-Myc expression (Kolligs et al. 1999) and RK3E lines transformed by other oncogenes (e.g., K-ras or GLI) (Fig. 6A; data not shown). An analysis of the time course of c-Myc activation following infection of RK3E cells with retroviruses encoding wild-type $\gamma$-catenin, revealed c-Myc was strongly induced at 2 days (Fig. 6B), essentially concordant with the time course of exogenous $\gamma$-catenin protein accumulation in the cells following retroviral infection (Fig. 6C). The S33Y $\beta$-catenin mutant protein only weakly activated c-Myc (Fig. $6 \mathrm{~B}$ ), despite the fact that the Flag epitope-tagged $\gamma$ - and $\beta$-catenin proteins were expressed at similar levels following retroviral infection of the RK3E cells (Fig. 6C). Consistent with the proposal that $\gamma$-catenin induced c-Myc expression via Tcf/Lef-dependent mechanisms, $\gamma$-catenin's activation of $\mathrm{c}-\mathrm{Myc}$ expression was blunted in a polyclonal RK3E cell line expressing a dominant negative Tcf- 4 protein (i.e., RK3E/Tcf-4 4 N31) (Fig. 6B). The induction of c-Myc expression in the RK3E/Tcf- $4 \Delta$ N31 line was not entirely inhibited, most likely because, as shown previously (Kolligs et al. 1999|, the cells have reduced but detectable Tcf/Lef function.

We next undertook studies to assess the ability of $\gamma$-catenin to act on the proximal c-MYC promoter. He et al. (1998) reported previously the proximal c-MYC promoter contains two Tcf-binding elements (TBE1 and
TBE2; Fig. 7A). Wild-type $\gamma$-catenin activated the c-MYC reporter gene construct Del-2, which contains both TBEs, with similar activity to that of the S33Y mutant $\beta$-catenin protein (Fig. 7B). Deletion of TBE1 (i.e., the Del-3 construct) reduced the ability of both proteins to activate gene expression, and deletion of both TBEs (i.e., Del-4) completely abrogated the effects of the catenin proteins (Fig. 7B). The nearly identical effects of wildtype $\gamma$-catenin and the S33Y mutant $\beta$-catenin protein on the c-MYC promoter construct contrasts with the roughly 15 -fold difference in the activity of the two proteins on the TOPFLASH model reporter construct (Fig. $7 \mathrm{C})$. Taken together, the findings on the differential activity of $\gamma$ - and $\beta$-catenin on distinct reporter gene constructs and the data on the differential effects of $\gamma$ - and $\beta$-catenin on endogenous c-MYC gene expression in RK3E cells suggest that interactions with other transcription factors and/or chromatin-associated proteins may have significant effects on the ability of the $\gamma$ - and $\beta$-catenin proteins to activate specific target genes in vivo.

\section{Discussion}

A significant role for $\beta$-catenin in human cancer was suggested initially because of its binding to the APC tumor suppressor protein and the apparent increased levels of $\beta$-catenin in the cytoplasm and nucleus of colon cancers with APC defects (Rubinfeld et al. 1993; Su et al. 1993; Munemitsu et al. 1995; Inomata et al. 1996). This view was bolstered by data showing $\beta$-catenin bound to Tcf/Lef factors (Behrens et al. 1996; Molenaar et al. 1996; Huber et al. 1996), and Tcf-4 transcription was strongly activated by $\beta$-catenin in cancers with APC defects (Korinek et al. 1997). Additional support was provided by the identification of activating mutations in $\beta$-catenin in some colon cancers lacking APC mutations as well as a subset of other cancers (Morin et al. 1997; Rubinfeld et al. 1997; de la Coste et al. 1998; Fukuchi et al. 1998; Miyoshi et al. 1998; Sparks et al. 1998; Voeller et al. 1998; Zurawel et al. 1998; Gamallo et al. 1999; GarciaRostan et al. 1999; Koch et al. 1999; Mirabelli-Primdahl et al. 1999; Park et al. 1999; Polakis 1999; Rimm et al. 1999; Wright et al. 1999). Subsequent in vitro and trans- 
A

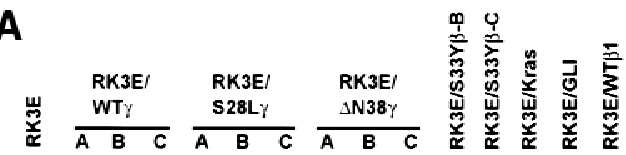

$\bullet-\bullet \bullet-\infty \bullet \bullet$

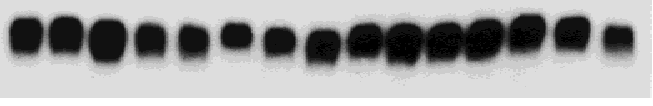

GAPDH

B
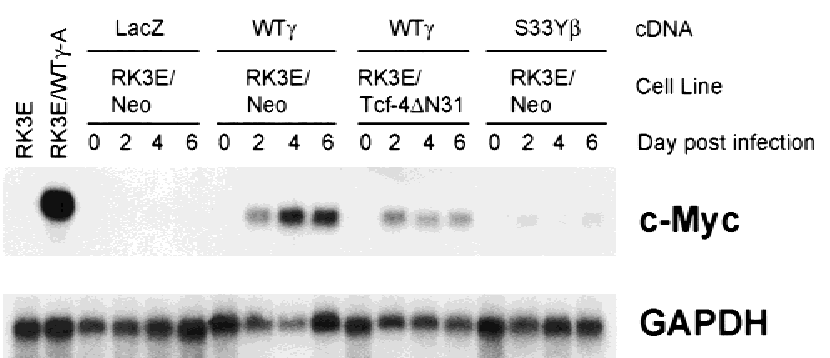

C

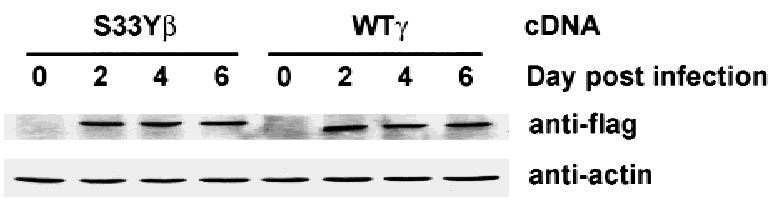

Figure 6. $\gamma$-Catenin, but not $\beta$-catenin, strongly activates c$M y c$ expression via Tcf/Lef-dependent mechanisms. (A) c-Myc expression is uniformly and markedly elevated in $\gamma$-catenintransformed RK3E lines compared with other cell lines, including parental RK3E cells, two $\beta$-catenin-transformed RK3E lines (RK3E/S33Y $\beta-B$ and RK3E/S33Y $\beta-C)$, RK3E cells transformed by other oncogenes (RK3E/Kras and RK3E/GLI), or RK3E cells with stable expression of wild-type $\beta$-catenin (RK3E/WT $\beta 1$ ). Northern blot analysis of c-Myc was carried out on total RNA from the various lines. After obtaining the autoradiograph for c-Myc, the blot was stripped and hybridized to a GAPDH cDNA probe to control for loading and transfer of RNA to the membrane. (B) $\gamma$-Catenin acutely activates $c-M y c$ expression in RK3E. RK3E/Neo and RK3E/Tcf- $4 \Delta \mathrm{N} 31$ cells were infected with the indicated retroviruses encoding control LacZ, wildtype $\gamma$-catenin, or S33Y $\beta$-catenin. Prior to infection (day 0), as well as time points of 2, 4, and 6 days post infection, cells were harvested and total RNA was isolated. Total RNA from RK3E cells and the RK3E/WT $\gamma$-A line were loaded as negative and positive controls, respectively, at left. Northern blot analyses for c-Myc expression and GAPDH were performed as in $A .(C)$ Expression of the Flag epitope-tagged S33Y $\beta$-catenin (S33Y $\beta$ ) and wild-type $\gamma$-catenin (WT $\gamma$ ) proteins in infected RK3E/Neo cells following infection of RK3E/Neo cells with the respective retroviruses. ECL-Western blot analysis with an anti-Flag antibody was carried out on whole-cell lysates prepared at various time points after infection. To confirm equal loading and transfer of proteins, blots were stripped and ECL-Western blotting with an anti-actin antibody was performed. genic studies have confirmed the transforming activity of the amino-terminal mutated forms of $\beta$-catenin found in cancer (Gat et al. 1998; Harada et al. 1999; Kolligs et al. 1999).

In contrast to the clear insights into the nature and role of $\beta$-catenin defects in cancer, evidence that
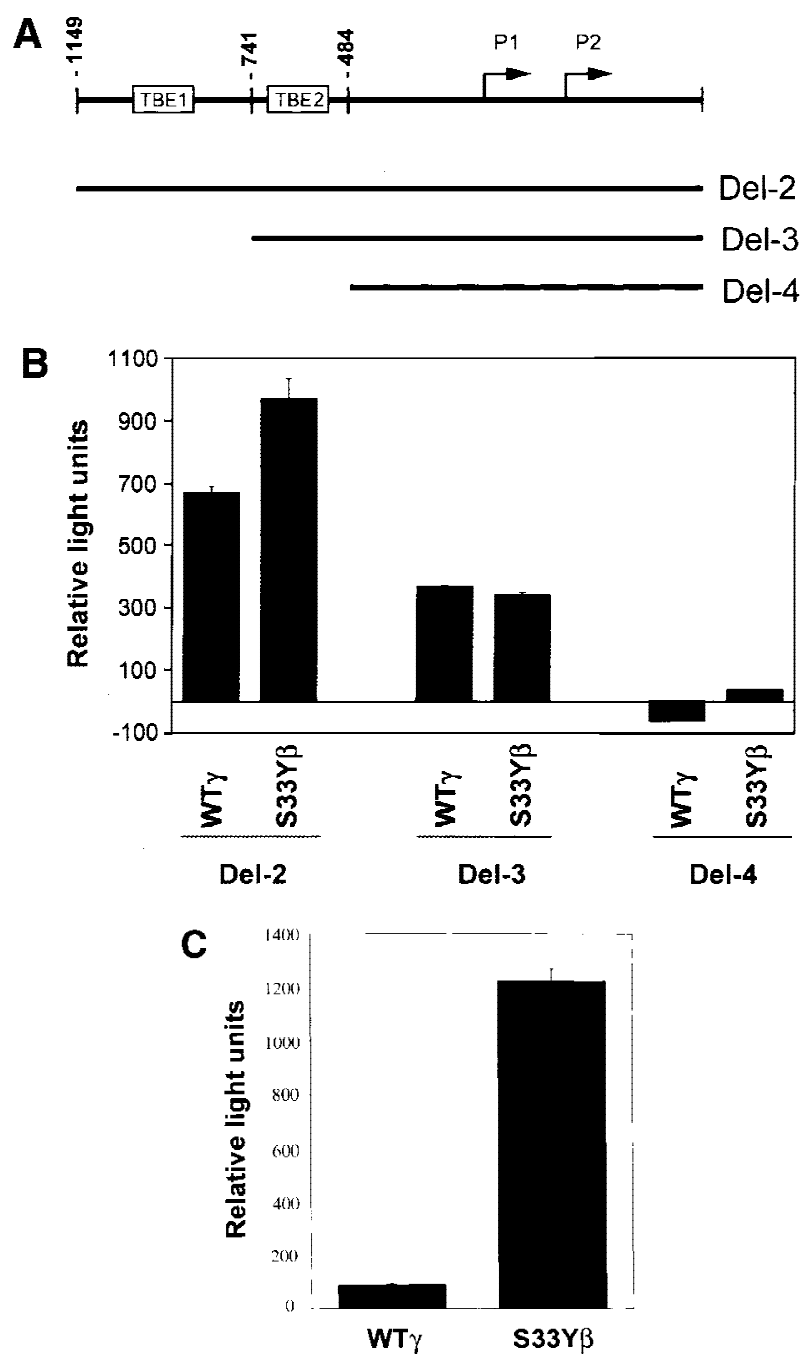

Figure 7. $\gamma$-Catenin activates expression from c-MYC reporter gene constructs. (A) Schematic diagram of the human c-MYC promoter region and sequences present in the Del-2, Del-3, and Del-4 reporter gene constructs of $\mathrm{He}$ et al. (1998). The relative location of the two TBEs is indicated. $(B)$ Ability of wild-type $\gamma$-catenin (WT $\gamma$ ) and the S33Y $\beta$-catenin mutant (S33Y $\beta$ ) to activate the c-MYC reporter gene constructs in 293 cells following transfection of pcDNA3 expression constructs. Luciferase activity was measured $48 \mathrm{hr}$ after transfection, and activities are indicated relative to that obtained with the empty pcDNA3 vector. The mean values and standard deviations from three experiments are shown. $(C)$ Differential activity of WT $\gamma$ and S33Y $\beta$ on the TOPFLASH reporter construct in 293 cells. Luciferase activities were determined $48 \mathrm{hr}$ after transfection. Mean values and standard deviations from three experiments are shown. The assays in $B$ and $C$ were normalized for transfection efficiency by cotransfection with the $\beta$-galactosidase expression vector $\mathrm{pcH} 110$. 
$\gamma$-catenin has an important role in cancer has been lacking. No $\gamma$-catenin mutations akin to those in $\beta$-catenin have been reported in primary human tumors, and, in fact, $\gamma$-catenin had growth suppressive effects in some cancer cells when overexpressed (Simcha et al. 1996). Thus, our results demonstrating that APC regulates $\gamma$-catenin and wild-type $\gamma$-catenin functions as an oncogene when deregulated, are the first to suggest that deregulation of $\gamma$-catenin may contribute to cancer. The transforming activity of wild-type $\gamma$-catenin in the RK3E system distinguishes it from $\beta$-catenin, which requires amino-terminal mutations to yield variants which transform RK3E cells. The ability of wild-type $\gamma$-catenin, but not wild-type $\beta$-catenin, to transform RK3E cells may reflect the possibility that the pathways and proteins targeting $\gamma$-catenin for degradation are less efficient than those regulating $\beta$-catenin. The requirement for $\mathrm{c}-\mathrm{Myc}$ function in $\gamma$-catenin-induced neoplastic transformation, but not that of $\beta$-catenin, also distinguishes the roles of $\gamma$ - and $\beta$-catenin in transformation.

Our data offer potential explanations for several puzzling results in the literature. For instance, it is well established that $70 \%-80 \%$ of colon cancers have inactivating mutations in APC (Kinzler and Vogelstein 1996), whereas only about $1 \%-10 \%$ of colon cancers have activating mutations in $\beta$-catenin (Kitaeva et al. 1997; Iwao et al. 1998; Sparks et al. 1998; Mirabelli-Primdahl et al. 1999; Polakis 1999; Samowitz et al. 1999|. In colon cancers with $A P C$ mutations, both $A P C$ alleles appear to be inactivated, and virtually all mutations result in either no stable APC protein or synthesis of a truncated APC protein that cannot coordinate the $\beta$-catenin, GSK3 $\beta$, and axin/conductin proteins (Kinzler and Vogelstein 1996; Polakis 1999; Peifer and Polakis 2000). Though much remains to be learned, a potential consequence of APC inactivation is that there is a substantial reduction in the efficiency with which the GSK3 $\beta$ and axin/conductin proteins phosphorylate $\beta$-catenin's amino terminus and promote its degradation. A quite diverse collection of mutations in $\beta$-catenin's amino terminus render it resistant to regulation by the APC/ GSK3 $\beta$ /axin complex yet still capable of binding Tcf/Lef factors and activating transcription. Thus, it is curious that $\beta$-catenin mutations are not seen more frequently in colon cancer, particularly in light of the fact that only one $\beta$-catenin allele need be mutated versus apparently two APC alleles. A hypothesis to account for the highly discordant frequencies of $A P C$ and $\beta$-catenin mutations in colon cancer is that APC has other vital growth regulatory functions besides promoting $\beta$-catenin phosphorylation and degradation. A corollary is that $\beta$-catenin activation has tangible, but weaker, cancer-promoting effects in colon epithelial cells than APC inactivation. Consistent with this prediction, although the frequencies of APC mutations in very small (early) colon adenomas and advanced carcinomas are similar (Kinzler and Vogelstein 1996), in some studies, $\beta$-catenin mutations have been reported to be more prevalent in small adenomas than carcinomas (Samowitz et al. 1999). Our data establishing that APC regulates $\beta$ - and $\gamma$-catenin in colon cancer, together with the observation that wild-type $\gamma$-catenin can function as an oncogene when its expression is deregulated, provide persuasive support for the hypothesis that APC has more than one critical regulatory function.

A second issue that may be clarified by our findings is the apparent rarity of mutations in $\gamma$-catenin's presumptive amino-terminal phosphorylation sequences in colon and other cancers (Sparks et al. 1998; Caca et al. 1999). Specifically, our data indicate that amino-terminal mutations in $\gamma$-catenin have minimal, if any, effect on its oncogenic potential in RK3E. The biological basis for this result appears to be that, in contrast to the effects of mutations in $\beta$-catenin, localized missense mutations in $\gamma$-catenin's presumptive GSK3 $\beta$ phosphorylation sites (e.g., the S28L mutant) do little to stabilize $\gamma$-catenin. Large in-frame deletions of $\gamma$-catenin's amino terminus (e.g., the $\Delta \mathrm{N} 122$ mutant), although substantially increasing the protein's relative stability, abrogate its ability to activate Tcf transcription. It is possible that wild-type $\gamma$-catenin expression might be sufficiently elevated to promote cancer as a result of amplification or rearrangements of the $\gamma$-catenin gene, and future studies may provide evidence this mechanism activates $\gamma$-catenin in cancer. Besides a highly selected cohort of mutations in $\gamma$-catenin itself, other defects which could potentially led to $\gamma$-catenin deregulation in cancer include inactivation of the APC, GSK3 $\beta$, or axin/conductin proteins. Thus far, inactivating mutations in GSK3 $\beta$ have not been reported in cancer, probably because GSK3 $\beta$ phosphorylates various other key growth regulatory proteins besides $\beta$ - and $\gamma$-catenin, such as proteins in insulin and growth-factor signaling (Sutherland et al. 1993; Cohen et al. 1997; Ross et al. 1999). As a result, GSK3 $\beta$ inactivation may actually be detrimental or even lethal to cells, rather than associated with neoplastic transformation. Mutations inactivating axin have recently been found in a minority of hepatocellular cancers, and such mutations alter $\beta$-catenin regulation with resultant activation of Tcf transcription (Satoh et al. 2000). Based on the fact that axin and GSK3 $\beta$ modulate $\gamma$-catenin levels in certain settings (Kodama et al. 1999), it seems reasonable to predict that axin defects in cancer might alter the regulation of both $\beta$ - and $\gamma$-catenin. Nevertheless, at present, the most common defect leading to altered $\gamma$-catenin regulation in cancer appears to be APC inactivation.

In cancers with APC inactivation, $\gamma$-catenin likely has a critical role in the neoplastic phenotype, such as through its ability to strongly activate c-Myc expression, a feature that among others may distinguish $\gamma$-catenin's role in cancer from $\beta$-catenin's. Prior work has already provided evidence that $\beta$ - and $\gamma$-catenin have distinct functions in other processes. For instance, whereas $\gamma$-catenin is known to localize to both adherens junctions and desmosomes, $\beta$-catenin does not associate with desmosomal proteins, except in $\gamma$-catenin-null mouse embryos (Ruiz et al. 1996; Bierkamp et al. 1999). Even though it redistributes in this setting, $\beta$-catenin cannot rescue the heart developmental defects in the $\gamma$-catenin-null embryos, which die between embryonic 
days 12 and 16. Similarly, $\gamma$-catenin is unable to compensate for $\beta$-catenin during development, as $\beta$-cateninnull mice die early in development because of defects in formation of the ectoderm layer (Haegel et al. 1995). It is unknown whether the distinct developmental anomalies seen in $\beta$-catenin versus $\gamma$-catenin knockout mice reflect differences between the functions of $\beta$ - and $\gamma$-catenin in cell adhesion, Wnt signaling, and/or unknown processes.

To the best of our knowledge, the data presented here are the first to suggest $\beta$ - and $\gamma$-catenin may have differential effects on Tcf/Lef target genes. Specifically, we found wild-type $\beta$-catenin had a roughly twofold greater effect and S33Y mutated $\beta$-catenin a roughly 15 -fold greater effect than wild-type $\gamma$-catenin in activating gene expression from a model promoter construct containing three Tcf-binding sites upstream of a minimal c-Fos promoter (i.e., TOPFLASH). In contrast, the ability of wildtype $\gamma$-catenin to activate $\mathrm{c}-M Y C$ reporter gene constructs was similar to that of S33Y $\beta$-catenin. Furthermore, $\gamma$-catenin activated endogenous c-Myc gene expression in RK3E cells considerably more strongly than the S33Y mutant $\beta$-catenin protein. The underlying mechanisms for their differential effects on the reporter gene constructs and on endogenous c-Myc are not yet clear, though differences in the interactions of the distantly related amino- and carboxy-terminal domains of $\gamma$ - and $\beta$-catenin with specific transcription factors, coactivators, and/or other chromatin-associated proteins are among the possible explanations. For instance, $\gamma$-catenin may enhance or facilitate the binding of certain transcription factors to promoters, whereas $\beta$-catenin may cooperate with other factors. The presence or absence of specific DNA-binding sites for certain transcription factors in regulatory elements of a particular Tcf/Lef-regulated target gene might account for its differential activation by $\beta$ - or $\gamma$-catenin. Alternatively, $\beta$ - and $\gamma$-catenin may differ in their ability to interact with certain chromatin remodeling proteins, some of which likely have differential effects on specific genes in vivo. Regardless of the particular mechanisms underlying their differential effects on c-Myc and potentially other target genes, the data presented here support the view that $\beta$ and $\gamma$-catenin are likely to have distinct but complementary roles in Wnt signaling and cancer development.

\section{Materials and methods}

\section{Plasmids}

The cloning of the wild-type and S28L mutant alleles of $\gamma$-catenin and the wild-type and S33Y mutant alleles of $\beta$-catenin has been described in detail previously (Caca et al. 1999; Kolligs et al. 1999). In brief, wild-type $\gamma$ - and $\beta$-catenin alleles were amplified by PCR from a normal human colon cDNA library (Clontech). The mutant $\gamma$-catenin allele S28L was cloned by PCR from the human gastric cancer cell line NCIN87; the $\beta$-catenin allele S33Y was cloned from the colorectal cancer cell line SW48. The wild-type $\gamma$-catenin allele was used as template for the PCR-based generation of the $\gamma$-catenin constructs $\Delta \mathrm{N} 38, \Delta \mathrm{N} 122, \Delta \mathrm{Arm}$, and $\Delta \mathrm{C} 687$. All $\gamma$ - and $\beta$-catenin cDNAs, including their carboxy-terminal Flag epitope tags, were subcloned into the eukaryotic expression vector pcDNA3
(Invitrogen). The sequence of all expression constructs was verified by automated or manual DNA sequencing. Further details on the generation of the pcDNA3 constructs will be provided on request. All $\gamma$ - and $\beta$-catenin cDNAs including their Flag epitope tags were further subcloned into the retroviral expression vector $\mathrm{pBMN}$. The empty $\mathrm{pBMN}$ vector and the $\beta$-galactosidaseexpressing vector pBMN-Z were kindly provided by G. Nolan (Stanford University, Stanford, CA). The reporter constructs pTOPFLASH and pFOPFLASH (provided by B. Vogelstein, Johns Hopkins University, Baltimore, MD) contain either three copies of the optimal Tcf-binding motif CCTTTGATC or three copies of the mutant motif CCTTTGGCC, respectively, upstream of a minimal c-Fos promoter driving luciferase expression. The cMYC reporter gene constructs Del-2, Del-3, and Del-4 were described previously by He et al. (1998). The pCH110 eukaryotic expression vector (Pharmacia), containing a functional LacZ gene downstream of a cytomegalovirus early region promoter/ enhancer element, was used as control for transfection efficiency in reporter assays.

\section{Cell lines and tissue culture}

Phoenix, RK3E, and 293 cells were grown in DMEM supplemented with $10 \%$ fetal bovine serum (FBS). HT29-APC and HT29-Gal cells (Morin et al. 1995) were provided by K. Kinzler (John Hopkins University) and B. Vogelstein, and the cells were cultured in McCoy's medium supplemented with 10\% FBS and $0.6 \mu \mathrm{g} / \mathrm{ml}$ Hygromycin B (Roche Molecular Biochemicals). The polyclonal RK3E-derived cell lines RK3E/Neo, RK3E/Tcf$4 \Delta \mathrm{N} 31$, RK3E/Myc $\Delta 106-143$, RK3E/WT $\beta-1$ have been described (Kolligs et al. 1999), and these lines were grown in DMEM/10\% FBS with $250 \mu \mathrm{g} / \mathrm{ml}$ G418 (GIBCO BRL/Life Technologies, Inc.). The propagation of recombinant retroviruses and the RK3E focus formation assay have been described in detail (Kolligs et al. 1999). Briefly, RK3E cells and derived lines were infected with the indicated retroviruses at $70 \%-80 \%$ confluence, the medium was changed twice weekly over a period of four weeks, then the plates were stained with Hank's balanced salt solution containing $1.5 \%$ glutaraldehyde (Sigma) and 0.06 gram methylene blue (Sigma) per $100 \mathrm{ml}$, and photographed. The clonal $\gamma$-catenin-transformed RK3E lines were isolated from $\gamma$-catenin-induced foci. Altogether, 6 independent lines transformed by each of the $3 \gamma$-catenin constructs (wild type, S28L, and $\Delta \mathrm{N} 38 \gamma$-catenin cDNAs) were established, for a total of 18 independent $\gamma$-catenin-transformed RK3E lines. To assess growth of transformed cells in reduced serum, $2 \times 10^{4}$ cells were seeded in triplicate in 6-well plates in DMEM with 10\% FBS. After $24 \mathrm{hr}$, the medium was replaced with fresh DMEM containing $0.5 \%$ FBS. After 1, 3, 5, and 7 days of culture in $0.5 \%$ FBS, the plates were trypsinized and viable cells were counted after trypan blue staining. For colony formation in agar assays, $1 \times 10^{4}$ cells were plated in 35-mm dishes in Noble agar (Difco), in a final concentration of $0.3 \%$ agar, $1 \times$ DMEM, and $20 \%$ FBS over a $0.6 \%$ agar medium layer. The agar surface was kept moist with growth medium during the three-week assay period, until the dishes were stained with methylene blue and photographed.

Immunofluorescence studies of $\beta$ - and $\gamma$-catenin in HT29-APC

HT29-APC and HT29-Gal cells were grown in chamber slides (Nalge Nunc International) with normal growth media for $24 \mathrm{hr}$; they were then incubated with fresh media supplemented with $150 \mu \mathrm{M}$ zinc chloride (Sigma). After a 6-hr exposure to zinc, no obvious apoptosis was present and APC expression was strongly induced in Western blot studies (data not shown). Hence, this 
was the time point used for immunofluorescence studies of APC's effects on $\beta$ - and $\gamma$-catenin. After washing with phosphate buffered saline (PBS), cells were fixed with $3 \%$ paraformaldehyde (Sigma) in PBS for $15 \mathrm{~min}$, then permeabilized for 15 min in $0.5 \%$ Triton X-100 (Sigma) and $1 \%$ goat serum (GIBCO) in PBS. Prior to incubation with the primary antibodies, the slides were blocked by a $30-$ min treatment with $20 \%$ goat serum $/ 0.2 \%$ Triton $\mathrm{X}-100$ in PBS. After washing in $2 \%$ goat serum $/ 0.2 \%$ Triton $\mathrm{X}-100$ in PBS, the slides were incubated for 2 hr with monoclonal antibodies against $\beta$ - or $\gamma$-catenin (Transduction Laboratories) in $2 \%$ goat serum $/ 0.2 \%$ Triton X-100 in PBS. After further washes, the slides were incubated with a secondary goat anti-mouse IgG antibody conjugated with Texas Red (Jackson Laboratories) for $30 \mathrm{~min}$. The slides were washed with PBS, cover-slipped using VECTASHIELD mounting medium (Vector Laboratories), examined with fluorescence optics on an Olympus AX70 microscope, and photographed at a magnification of $400 \times$.

\section{Immunohistochemistry for $\beta$ - and $\gamma$-catenin}

Sections $(5 \mu \mathrm{m})$ from formalin-fixed and paraffin-embedded carcinoma specimens were dewaxed in xylene, then rehydrated through graded alcohols. Antigen retrieval was performed by boiling in a microwave oven for $10 \mathrm{~min}$ in citrate buffer $(\mathrm{pH} 6.0$ Biogenex). Following blocking of endogenous peroxidase activity with $0.5 \%$ hydrogen peroxide in methanol, slides were incubated overnight at $4^{\circ} \mathrm{C}$ with monoclonal antibodies for $\beta$ - or $\gamma$-catenin (Transduction Laboratories) at concentrations of 1.0 $\mu \mathrm{g} / \mathrm{ml}$ and $5.0 \mu \mathrm{g} / \mathrm{ml}$, respectively. Detection was carried out by the avidin-biotin complex method (Vectastain Elite, Vector Laboratories) with diaminobenzidine as the chromogenic substrate. Slides were lightly counterstained with hematoxylin, then evaluated by light microscopy.

\section{Luciferase reporter gene assays}

Cells were plated in $35-\mathrm{mm}$ dishes $12 \mathrm{hr}$ prior to transfection. Transfections were performed with FuGENE6 (Boehringer Mannheim), according to the manufacturer's protocol, using $2 \mu \mathrm{l}$ of FuGENE6 per $1 \mu \mathrm{g}$ of transfected DNA. To measure Tcf reporter activity in the various RK3E lines, $0.5 \mu \mathrm{g}$ of pTOPFLASH or pFOPFLASH was cotransfected with $0.5 \mu \mathrm{g}$ of the control plasmid pCH110. To assess the ability of the various $\beta$ - and $\gamma$-catenin proteins to activate Tcf transcription, 293 cells were transfected with $1 \mu \mathrm{g}$ of the respective pcDNA3 expression construct, $0.5 \mu \mathrm{g}$ of pTOPFLASH or pFOPFLASH, and $0.5 \mu \mathrm{g}$ of $\mathrm{pCH} 110$. Analogous studies were carried out with the c-MYC reporter constructs Del-2, Del-3, and Del-4. The total mass of transfected DNA in the assays was kept constant by adding empty pcDNA3 plasmid, if necessary. Two days after transfection, the dishes were washed with PBS, and the cells were scraped from the plates and resuspended in reporter lysis buffer (Promega). Luciferase activities were measured in a luminometer after adding luciferase assay reagent (Promega) to the cell lysates. $\beta$-Galactosidase activities were determined according to standard methods and were used to control for transfection efficiency.

\section{Tumorigenicity in nude mice}

Groups of 5 mice (nu/nu-nuBR, Charles River Laboratories) were injected subcutaneously into each lower flank with $5 \times 10^{6}$ cells of each of the following cell lines: RK3E/WT $\gamma-\mathrm{A}, \mathrm{RK} 3 \mathrm{E} /$ WT $\gamma-\mathrm{B}, \mathrm{RK} 3 \mathrm{E} / \mathrm{S} 28 \mathrm{~L} \gamma-\mathrm{B}, \mathrm{RK} 3 \mathrm{E} / \Delta \mathrm{N} 38 \gamma-\mathrm{B}, \mathrm{RK} 3 \mathrm{E} / \mathrm{S} 33 \mathrm{Y} \beta-\mathrm{B}$, and parental RK3E cells. Prior to injection, cells were trypsinized, washed twice with DMEM, and resuspended in DMEM at a final concentration of $2.5 \times 10^{7}$ cells $/ \mathrm{ml}$. After 3 weeks, all mice injected with $\gamma$ - or $\beta$-catenin-transformed RK3E cells were sacrificed, and tumor diameters and weights were measured. Mice injected with parental RK3E cells were monitored for 8 weeks, without any evidence of tumor formation.

\section{Western blotting}

For all protein extracts, confluent cell culture dishes were washed with PBS and then scraped into PBS. After microcentrifugation, the cells were resuspended either in RIPA lysis buffer [Tris-buffered saline (TBS), $0.5 \%$ deoxycholate, $0.1 \%$ sodium dodecyl sulfate (SDS), 1\% Nonidet P-40] for whole-cell extracts or in NP-40 lysis buffer $(100 \mathrm{~mm} \mathrm{NaCl}, 50 \mathrm{~mm}$ Tris- $\mathrm{HCl}$ at $\mathrm{pH} 7.5,0.5 \%$ Nonidet P-40) for cytosolic extracts. PBS and lysis buffers were supplemented with proteinase inhibitors (complete proteinase inhibitors, Boehringer Mannheim). After a final centrifugation step, the protein concentrations of all lysates were determined by the bicinchoninic acid assay (Pierce). Equal masses of proteins were separated by electrophoresis in SDS- $8 \%$ polyacrylamide gels. After semidry transfer of the proteins to Immobilon $\mathrm{P}$ membranes (Millipore), the blots were incubated in TBS containing $0.1 \%$ Tween 20 (Sigma) and $10 \%$ nonfat dry milk to block nonspecific antibody binding. The antibody incubation steps were performed in TBS containing $0.05 \%$ Tween 20 and $5 \%$ nonfat dry milk. The anti-Flag M2 antibody (Sigma), the anti- $\gamma$-catenin and anti- $\beta$-catenin antibodies (Transduction Laboratories), and the anti-actin antibody (Sigma) were used at 1:5000 dilutions. The secondary horseradish peroxidase-conjugated goat anti-mouse antibody (Pierce) was used at a 1:20,000 dilution. The blots were subjected to enhanced chemiluminescence (ECL; Amersham Life Science) and exposed to X-Omat film (Kodak).

\section{Northern blotting}

Total RNA was extracted from cells using TRIZOL reagent (GIBCO BRL/Life Technologies, Inc.). Total RNA (10 $\mu \mathrm{g}$ ) was separated on $1.2 \%$ formaldehyde-agarose gels and transferred to Zeta-Probe GT-membranes (Bio-Rad) by capillary action. Rat c-Myc and glyceraldehyde-3-phosphate dehydrogenase (GAPDH) gene fragments were amplified by PCR and labeled with ${ }^{32} \mathrm{P}$-dCTP by random priming. Northern blot hybridization to ${ }^{32} \mathrm{P}$-labeled probes was carried out by standard methods. Signals were detected by exposure to BioMax-MS film (Kodak) at $-80^{\circ} \mathrm{C}$ with an intensifying screen.

\section{Acknowledgments}

We thank Drs. Kenneth Kinzler and Bert Vogelstein for generously providing the HT29-APC and HT29-Gal cells and the TOPFLASH, FOPFLASH, and c-MYC reporter vectors; Dr. Gary Nolan for the pBMN vector; and Drs. David Ginsburg, Elizabeth Petty, and Steve Weiss for their comments on the manuscript. This work was supported by NIH grants RO1CA70097 and 5 T32 CA09676-08 and Deutsche Forschungsgemeinschaft grant KO1826/1.

The publication costs of this article were defrayed in part by payment of page charges. This article must therefore be hereby marked "advertisement" in accordance with 18 USC section 1734 solely to indicate this fact.

\section{References}

Barth, A.I., I.S. Nathke, and W.J. Nelson. 1997. Cadherins, catenins and APC protein: Interplay between cytoskeletal complexes and signaling pathways. Curr. Opin. Cell Biol. 9: 683-690. 
Behrens, J. 1999. Cadherins and catenins: Role in signal transduction and tumor progression. Cancer Met. Rev. 18: 15-30.

Behrens, J., J.P. von Kries, M. Kuhl, L. Bruhn, D. Wedlich, R. Grosschedl, and W. Birchmeier. 1996. Functional interaction of $\beta$-catenin with the transcription factor LEF-1. Nature 382: 638-642.

Ben-Ze'ev, A. and B. Geiger. 1998. Differential molecular interactions of $\beta$-catenin and plakoglobin in adhesion, signaling and cancer. Curr. Opin. Cell Biol. 10: 629-639.

Bienz, M. 1999. APC: The plot thickens. Curr. Opin. Genet. Dev. 9: 595-603.

Bierkamp, C., H. Schwarz, O. Huber, and R. Kemler. 1999. Desmosomal localization of $\beta$-catenin in the skin of plakoglobin null-mutant mice. Development 126: 371-381.

Caca, K., F.T. Kolligs, X. Ji, M. Hayes, J. Qian, A. Yahanda, D.L. Rimm, J. Costa, and E.R. Fearon. 1999. $\beta$ - and $\gamma$-catenin mutations, but not E-cadherin inactivation, underlie T-cell factor/lymphoid enhancer factor transcriptional deregulation in gastric and pancreatic cancer. Cell Growth Diff. 10: 369376.

Cadigan, K.M. and R. Nusse. 1997. Wnt signaling: A common theme in animal development. Genes \& Dev. 11:32863305.

Cohen, P., D.R. Alessi, and D.A. Cross. 1997. PDK1, one of the missing links in insulin signal transduction. FEBS Lett. 410: $3-10$.

Crawford, H.C., B.M. Fingleton, L.A. Rudolph-Owen, K.J. Goss, B. Rubinfeld, P. Polakis, and L.M. Matrisian. 1999. The metalloproteinase matrilysin is a target of $\beta$-catenin transactivation in intestinal tumors. Oncogene 18: 2883-2891.

de La Coste, A., B. Romagnolo, P. Billuart, C.A. Renard, M.A. Buendia, O. Soubrane, M. Fabre, J. Chelly, C. Beldjord, A. Kahn et al. 1998. Somatic mutations of the $\beta$-catenin gene are frequent in mouse and human hepatocellular carcinomas. Proc. Natl. Acad. Sci. 95: 8847-8851.

Erisman, M.D., J.K. Scott, R.A. Watt, and S.M. Astrin. 1988. The c-myc protein is constitutively expressed at elevated levels in colorectal carcinoma cell lines. Oncogene 2: 367-378.

Fukuchi, T., M. Sakamoto, H. Tsuda, K. Maruyama, S. Nozawa, and S. Hirohashi. 1998. $\beta$-catenin mutation in carcinoma of the uterine endometrium. Cancer Res. 58: 3526-3528.

Gamallo, C., J. Palacios, G. Moreno, J. Calvo de Mora, A. Suarez, and A. Armas. 1999. $\beta$-catenin expression pattern in stage I and II ovarian carcinomas: Relationship with $\beta$-catenin gene mutations, clinicopathological features, and clinical outcome. Am. J. Path. 155: 527-536.

Garcia-Rostan, G., G. Tallini, A. Herrero, T.G. D'Aquila, M.L. Carcangiu, and D.L Rimm. 1999. Frequent mutation and nuclear localization of $\beta$-catenin in anaplastic thyroid carcinoma. Cancer Res. 59: 1811-1815.

Gat, U., R. DasGupta, L. Degenstein, and E. Fuchs. 1998. De novo hair follicle morphogenesis and hair tumors in mice expressing a truncated $\beta$-catenin in skin. Cell 95: 605-614.

Haegel, H., L. Larue, M. Ohsugi, L. Fedorov, K. Herrenknecht, and R. Kemler. 1995. Lack of $\beta$-catenin affects mouse development at gastrulation. Development 121: 3529-3537.

Harada, N., Y. Tamai, T. Ishikawa, B. Sauer, K. Takaku, M. Oshima, and M.M. Taketo. 1999. Intestinal polyposis in mice with a dominant stable mutation of the $\beta$-catenin gene. EMBO J. 18: 5931-5942.

Hart, M., J.P. Concordet, I. Lassot, I. Albert, R. del los Santos, H. Durand, C. Perret, B. Rubinfeld, F. Margottin, R. Benarous et al. 1999. The F-box protein $\beta$-TrCP associates with phosphorylated $\beta$-catenin and regulates its activity in the cell. Curr. Biol. 9: 207-210.

Hayashi, S., B. Rubinfeld, B. Souza, P. Polakis, E. Wieschaus, and A.J. Levine. 1997. A Drosophila homolog of the tumor suppressor gene adenomatous polyposis coli down-regulates $\beta$-catenin but its zygotic expression is not essential for the regulation of Armadillo. Proc. Nat1. Acad. Sci. 94: 242-247.

He, T.C., A.B. Sparks, C. Rago, H. Hermeking, L. Zawel, L.T. da Costa, P.J. Morin, B. Vogelstein, and K.W. Kinzler. 1998. Identification of c-MYC as a target of the APC pathway. Science 281: 1509-1512.

He, T.C., T.A. Chan, B. Vogelstein, and K.W. Kinzler. 1999. PPAR $\delta$ is an APC-regulated target of nonsteroidal anti-inflammatory drugs. Cell 99: 335-345.

Hsu, S.C., J. Galceran, and R. Grosschedl. 1998. Modulation of transcriptional regulation by LEF-1 in response to Wnt-1 signaling and association with $\beta$-catenin. Mol. Cell. Biol. 18: $4807-4818$.

Huber, O., R. Korn, J. McLaughlin, M. Ohsugi, B.G. Herrmann, and R. Kemler. 1996. Nuclear localization of $\beta$-catenin by interaction with transcription factor LEF-1. Mech. Dev. 59: 3-10.

Hulsken, J., W. Birchmeier, and J. Behrens. 1994. E-cadherin and APC compete for the interaction with $\beta$-catenin and the cytoskeleton. J. Cell Biol. 127: 2061-2069.

Inomata, M., A. Ochiai, S. Akimoto, S. Kitano, and S. Hirohashi. 1996. Alteration of $\beta$-catenin expression in colonic epithelial cells of familial adenomatous polyposis patients. Cancer Res. 56: 2213-2217.

Iwao, K., S. Nakamori, M. Kameyama, S. Imaoka, M. Kinoshita, T. Fukui, S. Ishiguro, Y. Nakamura, and Y. Miyoshi. 1998. Activation of the $\beta$-catenin gene by interstitial deletions involving exon 3 in primary colorectal carcinomas without adenomatous polyposis coli mutations. Cancer Res. 58: 1021-1026.

Kawahara K., T. Morishita, T. Nakamura, F. Hamada, K. Toyoshima, and T. Akiyama. 2000. Down-regulation of $\beta$-catenin by the colorectal tumor suppressor APC requires association with axin and $\beta$-catenin. J. Biol. Chem. 275: 8369-8374.

Kinzler, K.W. and B. Vogelstein. 1996. Lessons from hereditary colorectal cancer. Cell 87: 159-170.

Kitaeva, M.N., L. Grogan, J.P. Williams, E. Dimond, K. Nakahara, P. Hausner, J.W. DeNobile, P.W. Soballe, and I.R. Kirsch. 1997. Mutations in $\beta$-catenin are uncommon in colorectal cancer occurring in occasional replication error-positive tumors. Cancer Res. 57: 4478-4481.

Kitagawa, M., S. Hatakeyama, M. Shirane, M. Matsumoto, N. Ishida, K. Hattori, I. Nakamichi, A. Kikuchi, K. Nakayama, and K. Nakayama. 1999. An F-box protein, FWD1, mediates ubiquitin-dependent proteolysis of $\beta$-catenin. EMBO J. 18: 2401-2410.

Koch, A., D. Denkhaus, S. Albrecht, I. Leuschner, D. von Schweinitz, and T. Pietsch. 1999. Childhood hepatoblastomas frequently carry a mutated degradation targeting box of the $\beta$-catenin gene. Cancer Res. 59: 269-273.

Kodama, S., S. Ikeda, T. Asahara, M. Kishida, and A. Kikuchi. 1999. Axin directly interacts with plakoglobin and regulates its stability. J. Biol. Chem. 274: 27682-27688.

Kolligs, F.T., G. Hu, C.V. Dang, and E.R. Fearon. 1999. Neoplastic transformation of RK3E by mutant $\beta$-catenin requires deregulation of Tcf/Lef transcription but not activation of c-myc expression. Mol. Cell. Biol. 19: 5696-5706.

Korinek, V., M. Barker, P.J. Morin, D. van Wichen, R. de Weger, K.W. Kinzler, B. Vogelstein, and H. Clevers. 1997. Constitutive transcriptional activation by a $\beta$-catenin/Tcf complex in $\mathrm{APC}^{-/-}$colon carcinomas. Science 275: 1784-1787.

Maniatis, T. 1999. A ubiquitin ligase complex essential for the NF-kappaB, Wnt/Wingless, and Hedgehog signaling pathways. Genes \& Dev. 13: 505-510. 
Melhem, M.F., A.I. Meisler, G.G. Finley, W.H. Bryce, M.O. Jones, H. Tribbey, J.M. Pipas, and R.A. Koski. 1992. Distribution of cells expressing myc proteins in human colorectal epithelium, polyps, and malignant tumors. Cancer Res. 53: $5853-5864$.

Mirabelli-Primdahl, L., R. Gryfe, H. Kim, A. Millar, C. Luceri, D. Dale, E. Holowaty, B. Bapat, S. Gallinger, and M. Redston. 1999. $\beta$-catenin mutations are specific for colorectal carcinomas with microsatellite instability but occur in endometrial carcinomas irrespective of mutator pathway. Cancer Res. 59: 3346-3351.

Miyoshi, Y., K. Iwao, Y. Nagasawa, T. Aihara, Y. Sasaki, S. Imaoka, M. Murata, T. Shimano, and Y. Nakamura. 1998. Activation of the $\beta$-catenin gene in primary hepatocellular carcinomas by somatic alterations involving exon 3. Cancer Res. 58: 2524-2527.

Molenar, M., M. van de Wetering, M. Oosterwegel, J. PetersonMaduro, S. Godsave, V. Korinek, J. Roose, O. Destree, and H. Clevers. 1996. XTcf-3 transcription factor mediates $\beta$-catenin-induced axis formation in Xenopus embryos. Cell 86: 391-399.

Morin, P.J., B. Vogelstein, and K.W. Kinzler. 1995. Apoptosis and APC in colorectal tumorigenesis. Proc. Natl. Acad. Sci. 93: 7950-7954.

Morin, P.J., A.B. Sparks, V. Korinek, N. Barker, H. Clevers, B. Vogelstein, and K.W. Kinzler. 1997. Activation of $\beta$-cateninTcf signaling in colon cancer by mutations in $\beta$-catenin or APC. Science 275: 1787-1790.

Munemitsu, S., I. Albert, B. Souza, B. Rubinfeld, and P. Polakis. 1995. Regulation of intracellular $\beta$-catenin levels by the adenomatous polyposis (APC) tumor suppressor protein. Proc. Nat1. Acad. Sci. 92: 3046-3050.

Park, W.S., R.R. Oh, J.Y. Park, S.H. Lee, M.S. Shin, Y.S. Kim, S.Y. Kim, H.K Lee, P.J. Kim, S.T. Oh et al. 1999. Frequent somatic mutations of the $\beta$-catenin gene in intestinal-type gastric cancer. Cancer Res. 59: 4257-4260.

Peifer, M. and E. Wieschaus. 1990. The segment polarity gene armadillo encodes a functionally modular protein that is the Drosophila homolog of human plakoglobin. Cell 63: 11671176.

Peifer, M. and P. Polakis. 2000. Wnt signaling in oncogenesis and embryogenesis-a look outside the nucleus. Science 287: 1606-1609.

Peifer, M., C. Rauskolb, M. Williams, B. Riggleman, and E. Wieschaus. 1991. The segment polarity gene armadillo interacts with the wingless signaling pathway in both embryonic and adult pattern formation. Development 111: 1029-1043.

Polakis P. 1999. The oncogenic activation of $\beta$-catenin. Curr. Opin. Genet. Dev. 9: 15-21.

Rimm, D.L., K. Caca, G. Hu, F.B. Harrison, and E.R. Fearon. 1999. Frequent nuclear/cytoplasmic localization of $\beta$-catenin without exon 3 mutations in malignant melanoma. Am. J. Path. 154: 325-329.

Roose, J., G. Huls, M. van Beest, P. Moerer, K. van der Horn, R. Goldschmeding, T. Logtenberg, and H. Clevers. 1999. Synergy between tumor suppressor APC and the $\beta$-catenin-Tcf4 target Tcf1. Science 285: 1923-1926.

Ross, S.E., R.L Erickson, N. Hemati, and O.A. MacDougald. 1999. Glycogen synthase kinase 3 is an insulin-regulated C/EBP $\alpha$ kinase. Mol. Cell. Biol. 19: 8433-8441.

Rubinfeld, B., B. Souza, I. Albert, S. Munemitsu, and P. Polakis. 1995. The APC protein and E-cadherin form similar but independent complexes with $\alpha$-catenin, $\beta$-catenin, and plakoglobin. J. Biol. Chem. 270: 5549-5555.

Rubinfeld, B., P. Robbins, M. El-Gamil, I. Albert, E. Porfiri, and P. Polakis. 1997. Stabilization of $\beta$-catenin by genetic defects in melanoma cell lines. Science 275: 1790-1792.

Ruiz, P., V. Brinkmann, B. Ledermann, M. Behrend, C. Grund, C. Thalhammer, F. Vogel, C. Birchmeier, U. Gunthert, W.W. Franke et al. 1996. Targeted mutation of plakoglobin in mice reveals essential functions of desmosomes in the embryonic heart. J. Cell Biol. 135: 215-225.

Salic A., E. Lee, L. Mayer, and M.W. Kirschner. 2000. Control of $\beta$-catenin stability: Reconstitution of the cytoplasmic steps of the Wnt pathway in Xenopus egg extracts. Mol. Cell 5: 523-532.

Samowitz, W., M.D. Powers, L.N. Spirio, F. Nollet, F. van Roy, and M.L. Slattery. 1999. $\beta$-Catenin mutations are more frequent in small colorectal adenomas than in larger adenomas and invasive carcinomas. Cancer Res. 59: 1442-1444.

Satoh, S., Y. Daigo, Y. Furukawa, T. Kato, N. Miwa, T. Hishiwaki, T. Kawasoe, H. Ishiguro, M. Fujita, T. Tokino et al. 2000. AXIN1 mutations in hepatocellular carcinomas, and growth suppression in cancer cells by virus-mediated transfer of AXIN1. Nat. Genet. 24: 245-250.

Shibata, T., M. Gotoh, A. Ochiai, and S. Hirohashi. 1994. Association of plakoglobin with APC, a tumor suppressor gene product, and its regulation by tyrosine phosphorylation. Biochem. Biophys. Res. Comm. 203: 519-522.

Shtutman, M., J. Zhurinsky, I. Simcha, C. Albanese, M. D'Amico, R. Pestell, and A. Ben-Ze'ev. 1999. The cyclin D1 gene is a target of the $\beta$-catenin/LEF-1 pathway. Proc. Natl. Acad. Sci. 11: 5522-5527.

Simcha, I., B. Geiger, S. Yehuda-Levenberg, D. Salomon, and A. Ben-Ze'ev. 1996. Suppression of tumorigenicity by plakoglobin: An augmenting effect of $\mathrm{N}$-cadherin. I. Cell Biol. 133: 199-209.

Simcha, I., M. Shtutman, D. Salomon, J. Zhurinsky, E. Sadot, B. Geiger, and A. Ben-Ze'ev. 1998. Differential nuclear translocation and transactivation potential of $\beta$-catenin and plakoglobin. J. Cell Biol. 141: 1433-1448.

Sparks, A.B., P.J. Morin, B. Vogelstein, and K.W. Kinzler. 1998. Mutational analysis of the APC/ $\beta$-catenin/Tcf pathway in colorectal cancer. Cancer Res. 58: 1130-1134.

Su, L.K., B. Vogelstein, and K.W. Kinzler. 1993. Association of the APC tumor suppressor protein with catenins. Science 262: 1734-1737.

Sutherland, C., I.A. Leighton, and P. Cohen. 1993. Inactivation of glycogen synthase kinase- $3 \beta$ by phosphorylation: New kinase connections in insulin and growth-factor signaling. Biochem. J. 296: 15-19.

Tetsu, O. and F. McCormick. 1999. $\beta$-catenin regulates expression of cyclin D1 in colon carcinoma cells. Nature 398: 422426.

Voeller, H.J., C.I. Truica, and E.P. Gelmann. 1998. $\beta$-catenin mutations in human prostate cancer. Cancer Res. 58: 2520 2523.

Willert, K. and R. Nusse. 1998. $\beta$-catenin: A key mediator of Wnt signaling. Curr. Opin. Genet. Dev. 8: 95-102.

Winston, J.T., P. Strack, P. Beer-Romero, C.Y. Chu, S.J. Elledge, and J.W. Harper. 1999. The SCF $\beta$-TRCP-ubiquitin ligase complex associates specifically with phosphorylated destruction motifs in IкB $\alpha$ and $\beta$-catenin and stimulates IкB $\alpha$ ubiquitination in vitro. Genes \& Dev. 13: 270-283.

Wright, K., P. Wilson, S. Morland, I. Campbell, M. Walsh, T. Hurst, B. Ward, M. Cummings, and G. Chenevix-Trench. 1999. $\beta$-catenin mutation and expression analysis in ovarian cancer: Exon 3 mutations and nuclear translocation in 16\% of endometroid tumours. Int. J. Cancer 82: 625-629.

Zurawel, R.H., S.A. Chiappa, C. Allen, and C. Raffel. 1998. Sporadic medulloblastomas contain oncogenic $\beta$-catenin mutations. Cancer Res. 58: 896-899. 


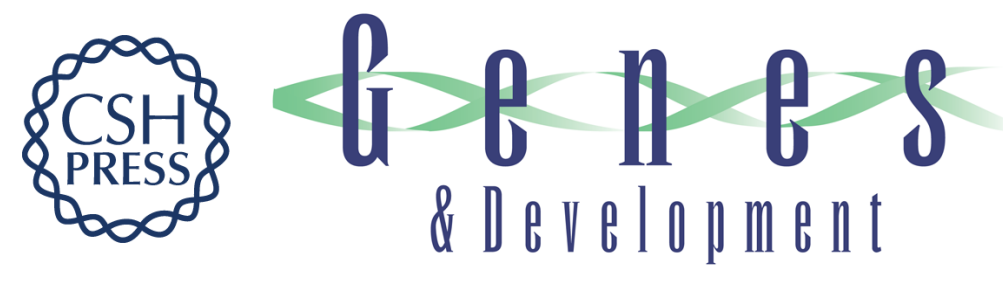

\section{$\gamma$-Catenin is regulated by the APC tumor suppressor and its oncogenic activity is distinct from that of $\beta$-catenin}

Frank T. Kolligs, Barbara Kolligs, Karen M. Hajra, et al.

Genes Dev. 2000, 14:

Access the most recent version at doi:10.1101/gad.14.11.1319

References

This article cites 68 articles, 44 of which can be accessed free at:

http://genesdev.cshlp.org/content/14/11/1319.full.html\#ref-list-1

\section{License}

Email Alerting

Receive free email alerts when new articles cite this article - sign up in the box at the top

Service right corner of the article or click here.

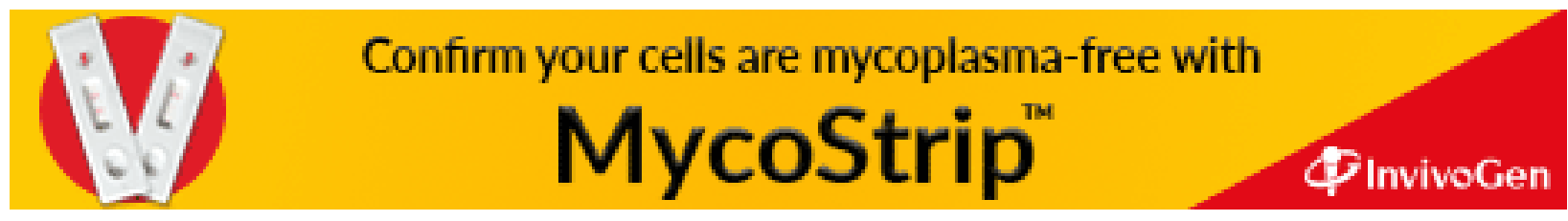

